\title{
EWA DUBAS
}

KAMIL ZIELIŃSKI

MONIKA KRZEWSKA

IWONA ŻUR

ANNA NOWICKA

\section{KATARZYNA JUZOŃ}

Instytut Fizjologii Roślin im. Franciszka Górskiego PAN w Krakowie

Kierownik Tematu: dr hab. Ewa Dubas Instytut Fizjologii Roślin im. Franciszka Górskiego PAN

w Krakowie, ul. Niezapominajek 21, 30-239 Kraków, tel. 124253301 wew. 39; sekretariat IFR PAN

tel. 124251833 wew. 102, e-mail: e.dubas@ifr-pan.edu.pl

Prace zostały wykonane $w$ ramach badan podstawowych na rzecz postępu biologicznego $w$ produkcji roślinnej na podstawie decyzji Ministra Rolnictwa $i$ Rozwoju Wsi nr HOR.hn.802.15.2018, Zadanie 84.

\section{Identyfikacja czynników determinujących efektywność otrzymywania podwojonych haploidów żyta (Secale cereale L.) metodami androgenezy i krzyżowań oddalonych}

\section{Identification of factors determining the efficiency of doubled haploids production in rye (Secale cereale L.) through androgenesis and distant crosses \\ Słowa kluczowe: androgeneza, glutation, haploidy, krzyżowania oddalone, programowana śmierć komórki, żyto}

Celem nadrzędnym proponowanego projektu było określenie przyczyn braku podatności oraz identyfikacja czynników warunkujących przełamanie barier haploidyzacji żyta z wykorzystaniem dwóch metod: androgenezy w kulturach pylników i izolowanych mikrospor oraz krzyżowań oddalonych żyta z kukurydzą (Secale cereale L. ssp. cereale $\times$ Zea mays L.). Celami pośrednimi były: (1) wybór optymalnej metody indukcji haploidalnych zarodków żyta (androgenezy i/lub krzyżowań oddalonych), (2) ustalenie optymalnych warunków kiełkowania i regeneracji zarodków/kalusów dla uzyskania na drodze androgenezy i/lub krzyżowań oddalonych roślin diploidalnych (DH) żyta, (3) identyfikacja fizjologicznego podłoża warunkującego efektywną produkcję DH żyta. 
Wyznaczone cele realizowane były etapami:

- Temat badawczy 2015-2018: Ocena efektywności haploidyzacji żyta metodami androgenezy w kulturach pylników i izolowanych mikrospor oraz krzyżowań oddalonych z kukurydzą.

- Temat badawczy 2015-2016: Określenie odpowiedniej fazy rozwoju gametofitu oraz optymalizacja warunków indukcji haploidalnych zarodków żyta w wybranej w Zb1 metodzie.

— Temat badawczy 2016-2017: Optymalizacja warunków kiełkowania i regeneracji zarodków/kalusów dla uzyskania roślin diploidalnych (DH) żyta.

— Temat badawczy 2017-2018: Identyfikacja fizjologicznego podłoża warunkującego efektywną produkcję DH żyta.

Przeprowadzone badania nad haploidyzacją genomu wykonano na mieszańcach pokolenia $\mathrm{F}_{1}$ (samopylnego oraz obcopylnego) żyta ozimego (Secale cereale $\mathrm{L}$, ssp. cereale) udostępnionych przez polskie spółki hodowli roślin. Testowano metody: androgenezy w kulturach pylników i izolowanych mikrospor oraz krzyżowań oddalonych żyta z kukurydzą.

Scharakteryzowano testowane techniki haploidyzacji w indukcji zarodków (kultury pylnikowe, izolowanych mikrospor oraz krzyżowań oddalonych z kukurydzą) i wybrano najbardziej efektywną metodę. Na tej podstawie dokonano selekcji genotypów skrajnie zróżnicowanych pod względem podatności na haploidyzację, które wykorzystano następnie, jako obiekty modelowe w badaniu fizjologicznego podłoża indukcji i regeneracji DH żyta na dalszych etapach projektu. W ramach zadań badawczych określono: (1) optymalną fazę rozwoju gametofitu żeńskiego do indukcji haploidalnych zarodków żyta w metodzie krzyżowań oddalonych. Wykazano, że na efektowność metody krzyżowania oddalonego u żyta ma wpływ przede wszystkim genotyp, okres pomiędzy kastrowaniem a zapylaniem (4 lub 6 dni) oraz rodzaj stosowanej auksyny (Marcińska i in., 2018); (2) optymalną fazę rozwoju gametofitu męskiego do indukcji haploidalnych zarodków żyta $\mathrm{w}$ androgenezie. Wykazano wpływ genotypu roślin macierzystych i rodzaju wstępnego traktowania kłosów na żywotność oraz na średnią ilość poszczególnych typów komórek, będących w optymalnym stadium do zainicjowania androgenezy (w stadium jednojądrowym) oraz komórek inicjujących rozwój sporofitowy (po symetrycznym podziale) $\mathrm{W}$ dniu izolacji $\mathrm{z}$ kłosów; (3) warunki kiełkowania i regeneracji zarodków/kalusów dla uzyskania roślin diploidalnych (DH) żyta. Wykazano wpływ zastosowanej pożywki indukcyjnej i regeneracyjnej na efektywność androgenezy; (4) zidentyfikowano fizjologiczne podłoże warunkujące efektywną produkcję DH żyta. Wykazano, że na podatność na indukcję androgenezy ma wpływ endogenne stężenie glutationu w tkance wegetatywnej liścia flagowego i w pylnikach. Przedstawiono, na podstawie analizy aktywności enzymów szlaku glutationowego, jak aktywowany jest system antyoksydacyjny w pylnikach wyizolowanych z kłosów poddanych traktowaniu wstępnemu w odniesieniu do efektywności indukcji androgenezy i regeneracji.

Czynnikami, które bardzo często decydowały o przebiegu kultury w przedstawianych doświadczeniach były (1) genotyp rośliny macierzystej, (2) interakcja pomiędzy genotypem i traktowaniem wstępnym kłosów oraz (3) interakcja pomiędzy genotypem, 
traktowaniem wstępnym kłosów oraz rodzajem zastosowanej pożywki indukcyjnej i regeneracyjnej. Wykazano, że genotypowe uwarunkowanie podatności na androgenezę zależy od wydajności system antyoksydacyjnego, w tym endogennego stężenia glutationu oraz aktywności badanych enzymów metabolizujących ten niskocząsteczkowy antyoksydant (Zieliński i in., 2017, 2018 a,b).

Zastosowane modyfikacje traktowania wstępnego kłosów (niska temperatura, stres osmotyczny, łagodzenie stresu oksydacyjnego łącznie $\mathrm{z}$ chemiczną modyfikacją aktywności enzymu metabolizującego glutation) podtrzymywały żywotność komórek oraz chroniły DNA jądrowe w mikrosporach przed fragmentacją (Zieliński i in., 2017, 2018c). Dodatkowo, optymalizacja składu pożywek na etapie indukcji (glutamina, arabinogalaktany, związki miedzi, węgiel aktywowany, phytagel) i regeneracji (arabinogalaktany, związki miedzi) istotnie wpłynęła na indukcję procesu androgenezy oraz regenerację roślin DH żyta z uzyskanych struktur androgenicznych. Zaproponowane $\mathrm{w}$ projekcie warunku kultury in vitro ( $\mathrm{w}$ kulturach pylników oraz izolowanych mikrospor) poskutkowały przełamaniem oporności/podniesieniem efektywności parametrów indukcji AS/SP i regeneracji $\mathrm{R}_{\text {Total }} \mathrm{u}$ wszystkich linii. W przypadku kultur zawiesinowych mikrospor, istotnym okazało się zastosowanie inhibitorów PCD in vitro, co pozwoliło na przełamanie oporności u linii opornych i kilkukrotne podniesienie efektywności procesu indukcji androgenezy u linii podatnej.

Analiza cytologiczna oraz molekularna, uzyskanych w kulturach pylników i izolowanych mikrospor zarodków, pozwoliła na częściowe znalezienie przyczyny niskiej efektywności procesu androgenezy. Zilustrowano, że przyczyną nieprawidłowości rozwoju zarodków androgenicznych u żyta jest nie tylko fragmentacja DNA, ale także aktywność proteolityczna enzymów PCD, w tym kaspazy 1.

\section{LITERATURA}

Marcińska I., Czyczyło-Mysza I., Skrzypek E., Warchoł M., Zieliński K., Dubas E. 2018. Obtaining of winter rye (Secale cereale L. ssp. cereale) haploid embryos through hybridization with maize (Zea mays L.). Cereal Research Communications 46 (3) DOI: 10.1556/0806.46.2018.029.

Zieliński K., Nowicka A., Żur I., Krzewska M., Dubas E. 2017. Programowana śmierć komórki samobójczym zagrożeniem dla indukcji androgenezy u żyta (Secale cereale L.). III Ogólnopolska konferencja doktorantów nauk o życiu BIOOPEN, Łódź, 11-12 maj 2017: 63 s.

Zieliński K., Fodor J., Krzewska M., Nowicka A., Żur I., Dubas E. 2018 a. Glutationowa równowaga w indukcji androgenezy u żyta (Secale cereale L.). IV Ogólnopolska konferencja doktorantów nauk o życiu BIOOPEN, Łódź, 24-25 maja 2018, p.: 85.

Zieliński K., Krzewska M., Nowicka A., Żur I., Fodor J., Dubas E. 2018 b. Redox regulation of androgenesis in rye (Secale cereale L.). $11^{\text {th }}$ International Conference 'Plant Functioning Under Environmental Stress', Krakow, 12-15 September 2018: 82 p.

Zieliński K., Krzewska M., Nowicka A., Juzoń K., Żur I., Dubas E. 2018 c. Programmed cell death (PCD) and androgenesis induction in rye (Secale cereale L.). $11^{\text {th }}$ International Conference 'Plant Functioning Under Environmental Stress', Krakow, 12-15 September 2018: 3. 
